IZADP No. 1953

The Effects of State-Sponsored Merit Scholarships on Course Selection and Major Choice in College

Christopher Cornwell

Kyung Hee Lee

David B. Mustard

J anuary 2006 


\title{
The Effects of State-Sponsored Merit Scholarships on Course Selection and Major Choice in College
}

\author{
Christopher Cornwell \\ University of Georgia \\ Kyung Hee Lee \\ Sogang University \\ David B. Mustard \\ University of Georgia \\ and IZA Bonn
}

Discussion Paper No. 1953

January 2006

\author{
IZA \\ P.O. Box 7240 \\ 53072 Bonn \\ Germany \\ Phone: +49-228-3894-0 \\ Fax: +49-228-3894-180 \\ Email: iza@iza.org
}

\begin{abstract}
Any opinions expressed here are those of the author(s) and not those of the institute. Research disseminated by IZA may include views on policy, but the institute itself takes no institutional policy positions.
\end{abstract}

The Institute for the Study of Labor (IZA) in Bonn is a local and virtual international research center and a place of communication between science, politics and business. IZA is an independent nonprofit company supported by Deutsche Post World Net. The center is associated with the University of Bonn and offers a stimulating research environment through its research networks, research support, and visitors and doctoral programs. IZA engages in (i) original and internationally competitive research in all fields of labor economics, (ii) development of policy concepts, and (iii) dissemination of research results and concepts to the interested public.

IZA Discussion Papers often represent preliminary work and are circulated to encourage discussion. Citation of such a paper should account for its provisional character. A revised version may be available directly from the author. 
IZA Discussion Paper No. 1953

January 2006

\section{ABSTRACT \\ The Effects of State-Sponsored Merit Scholarships on Course Selection and Major Choice in College}

A common justification for HOPE-style merit-aid programs is to promote and reward academic achievement, thereby inducing greater investments in human capital. However, grade-based eligibility and retention rules encourage other behavioral responses. Using data extracted from the longitudinal records of all undergraduates who enrolled at the University of Georgia (UGA) between 1989 and 1997, we estimate the effects of HOPE on college GPA, course selection, and major choice, treating non-residents as a control group. First, we find that HOPE increased resident freshman GPA by 0.13 point, while its effect on GPA after the first year is weak. Second, HOPE reduced the number of credit hours completed in math and science core curriculum courses during the first year, and this effect persisted into the second at roughly the same magnitude. Over both years, the estimated program effects imply that residents completed about 1.2 fewer math and sciences credit hours. Finally, the likelihood that the average resident freshman would choose to major in Education jumped 1.2 percentage points relative to their out-of-state counterparts after HOPE was introduced and the scholarship's influence on this decision was more pronounced for women and whites.

JEL Classification: 12

Keywords: merit aid, education finance

Corresponding author:

David B. Mustard

Department of Economics

Terry College of Business

University of Georgia

Athens, GA 30602

USA

Email: mustard@terry.uga.edu

\footnotetext{
* Preliminary draft. Cornwell and Mustard gratefully acknowledge the support of the NSF under grant SES-9986469 and Terry College of Business through its Terry-Sanford Research Grant Program. Lee's research was funded in part by the American Education Finance Association.
} 


\section{Introduction}

Until the 1990s, the use of merit-based financial aid was largely restricted to individual colleges attempting to attract academically gifted students to their institutions. Since then at least fifteen states have established meritbased college scholarships, typically without means tests. ${ }^{1}$ The template for these new state programs has been Georgia's HOPE ("Helping Outstanding Pupils Educationally") Scholarship.

Funded by a state lottery, Georgia's HOPE Scholarship was introduced in 1993. It provides tuition, mandatory fees, and a book allowance for all eligible high-school graduates seeking a degree at one of the state's public postsecondary institutions. The award value has accounted for at least $40 \%$ of the total cost of attendance at the state's top public universities, amounting to over $\$ 4500$ in the 2004-05 academic year. HOPE recipients attending in-state private institutions receive a fixed payment of $\$ 3000$. To qualify, a student must be a Georgia resident and have graduated from a Georgia high school with a "B" average. Initially, there was a household income cap of $\$ 66,000$, but it was raised to $\$ 100,000$ in 1994, and abolished entirely in 1995 . To retain the scholarship, a student must maintain a 3.0 grade-point average (GPA) in college. Through July 2004, more than $\$ 1.4$ billion in scholarship funds have been disbursed to over 600,000 students.

Three common justifications are offered for merit scholarships like HOPE. One is to increase college enrollments in the state. A second is to keep their best and brightest high-school graduates from attending college elsewhere. As far as HOPE is concerned, Cornwell, Mustard, and Sridhar (2005) show that it has raised overall enrollments in Georgia colleges - by 6 percent between 1993 and 1997-but "keeping the best and brightest in state" accounts for as little as quarter of the overall program effect. Additionally, their estimated HOPE-induced enrollment increase amounts to less than 15 percent

\footnotetext{
${ }^{1}$ See Cornwell, Leidner and Mustard (2004) for a review of these programs.
} 
of award recipients.

The third justification for such scholarships is the incentive they create for academic achievement. How strong is this incentive? To what extent do they promote other behavioral responses that may weaken their impact on learning? The requirements for HOPE eligibility and retention effectively put a premium on maintaining a 3.0 GPA in high school and college, raising the returns to a range of potentially grade-enhancing decisions. There has been little empirical work dealing with the influence of this grade premium on students' academic choices. ${ }^{2}$

One exception is our earlier study, Cornwell, Lee, and Mustard (2005) (hereafter CLM), which considered the effects of HOPE on course-load adjustments. Using data from the longitudinal records of all undergraduates who enrolled at the University of Georgia (UGA) between 1989 and 1997, we compared the choices of in-state and out-of-state students before and after HOPE was implemented, using the non-residents, who cannot receive the scholarship, as a control group. We found that HOPE caused about a 10 percent drop in the probability of completing a full-course load and 1 credit reduction in annual course credits completed for the typical student.

The human-capital consequences of reducing annual credit hours are not clear. Progress toward graduation may be slowed, but it could aid in the transition to college and facilitate learning in the enrolled courses. The same probably would not be said about taking particular courses because the expected grade is high relative to the required effort, or choosing a major based on the grade distributions of its associated courses.

\footnotetext{
${ }^{2}$ Dee and Jackson (1999) examined the incidence of scholarship loss in the 1996 entering class of Georgia Tech freshmen, but were not concerned with how the HOPE retention rules affected behavior. Henry, Rubenstein, and Bugler (2004) compared the academic records of "borderline" HOPE-eligible Georgia high-school graduates with a group of non-qualifiers and found that students in the first group had higher college GPAs and probabilities of graduating in four years and completed more college credits. However, these results cannot be construed as causal effects of HOPE, because all Georgia high-school students operate under the same incentives in before college, and those that do not qualify then can become eligible in college.
} 
Using survey data on almost 8,000 students who graduated from the University of Texas between 1980 and 2000, Hamermesh and Donald (2004) show that earnings differ significantly across undergraduate majors, and the course-taking pattern in college affects earnings even within a major. For example, they find that business majors earned 50 to 70 percent more than education majors, even after controlling for college achievement (overall GPA, and credits and grades in upper-division science and math courses), individual characteristics (gender, marital status, class year, highest degree obtained, and weekly work hours), income in the high-school community, and survey non-response. In addition, they report that students who took more advanced science or math courses in college earned more after graduation, all else equal. ${ }^{3}$ An obvious implication of the Hamermesh and Donald results is that responding to the scholarship retention rules by choosing a particular major or fewer math and science courses is costly.

In this paper, we go beyond our earlier analysis of course-load adjustment to investigate HOPE's impact on course and major selection. We use the UGA student-record data from our previous study and again treat out-ofstate students as a control group. ${ }^{4}$ First, we quantify by HOPE's effect on college GPA and then examine its role in sorting students across corecurriculum courses and influencing the selection of majors.

Our findings can be summarized as follows. First, the GPAs of resident freshmen rose almost .13 points because of HOPE, an effect compa-

\footnotetext{
${ }^{3}$ Rose and Betts (2004) show that the effect of math courses on earnings extends to the high-school level.

${ }^{4}$ As discussed by CLM, the population of non-residents could be affected by HOPE if states that traditionally supply students to UGA introduced merit scholarships, or if the program allowed UGA to transfer institutional aid previously allocated to Georgia residents to out-of-state students. However, as discussed in CLM, neither happened during our sample period in an empirically meaningful way. First, Florida's Bright Futures is the only other HOPE-like scholarship introduced during our sample period and it did not start until the last year. Second, the only evidence for institutional aid transfers occurs in 1996 and 1997 when UGA began awarding Charter Scholarships (which provided about $\$ 2000$ in direct aid and an out-of-state tuition waiver) to non-residents, but less than fifty of these scholarships were awarded in these two years to all (not just freshmen) out-of-state students.
} 
rable in magnitude to a 100-point SAT score increase. However, evidence for scholarship-induced grade improvements beyond the first year is weak. Second, HOPE reduced the number of credit hours completed in math and science core curriculum courses during the first year, and this effect persisted into the second year at roughly the same magnitude. Over both years, the estimated program effects imply that residents completed about 1.2 fewer math and sciences credit hours. Finally, the likelihood that the average resident freshman would major in Education jumped 1.2 percentage points relative to their out-of-state counterparts after HOPE was introduced. HOPE's influence on this decision was greater for women and whites.

\section{Data}

The data for our analysis cover all undergraduates enrolled at UGA between 1989 and 1997 and come from three sources. The Office of Student Financial Aid provided each student's HOPE status. Pre-college and personal characteristics, such as SAT scores, high school attended, residency, ethnicity, gender, and age, were obtained from the Undergraduate Admissions Office. ${ }^{5}$ We acquired high-school achievement and course enrollment data from the Registrar's Office. These included high-school GPA (HSGPA) and advanced placement (AP) credits, core course selection (at UGA) and declared major, plus matriculation and graduation terms (if available),

In total, the data set contains 38,193 undergraduates. However, we restrict the sample to those who enrolled at UGA as first-time freshmen (FTF) - those who have not attended any postsecondary school before entering UGA - because we are concerned with HOPE's influence from the

\footnotetext{
${ }^{5}$ The College Board recentered SAT scores for tests taken on or after 1 April 1995 to reestablish the average SAT I verbal and math scores near the midpoint of the 200-to- 800 scale. SAT scores from the Admissions Office for students in 1989 through 1994 classes were on the original scale. We recentered pre-April 1995 SAT scores using the College Board's SAT I individual score conversion table.
} 
beginning of a student's college career. This is particularly important in the analysis of core course selection, which dominates the curricular decisions in the first year or two years of college. In addition, we confine our attention to FTF we deem "typical" - students who matriculated at UGA in the fall term of the same year as they graduated from high school. Thus, we exclude transfer students and students who matriculated at UGA before or after the fall term following their high-school graduation.

Table 1 breaks down the typical FTF by residency and scholarship status for each class year. During HOPE's first year, when the $\$ 66,000$ income cap was in force, only 35.2 percent (949) of typical FTF Georgia residents entered with the scholarship. The percentage with HOPE rose to 75.5 in 1994 after the income cap was increased to $\$ 100,000$. Since the cap was eliminated entirely in 1995, virtually all resident, typical FTF qualify for HOPE. The gradual removal of the income cap leads to the treatment group in 1993 and 1994 being comprised of residents who are not scholarship recipients. These individuals may have expected coverage to be expanded and therefore acted as if they faced the same incentives as students with HOPE. If not, their presence in the treated group will cause the effects of HOPE to be underestimated, because there is no additional cost for them in failing to maintain a 3.0 GPA. We address this issue by conducting separate analyzes contrasting the last cohort never to benefit from HOPE (the 1990 class) and the first cohort to have "full coverage" (the 1995 class).

To set the stage for our empirical analysis, consider Figure 1, which plots kernel density estimates of cumulative GPA distributions of typical resident and non-resident FTF in the 1990 and 1995 classes. ${ }^{6}$ In 1990, the grade distribution for out-of-state students lies to the right of the resident distribution and exhibits less variance. By 1995, the opposite description applied. The resident distribution shifted to the right of the non-resident distribu-

\footnotetext{
${ }^{6}$ We used the KDE procedure in SAS 8.2, a Gaussian kernel, and the Sheather-Jones plug-in method to compute the bandwidth.
} 
tion and tightened dramatically, establishing a conspicuous peak around 3.0. These changes suggest a clear role for HOPE's grade-based retention rules in explaining the relative gains of resident freshmen. The question we are interested in is the degree to which these gains can be attributed adjustments at the course or major level.

\section{Georgia's HOPE Scholarship}

\subsection{Award Value, Eligibility, and Retention}

HOPE can be used at 103 postsecondary institutions in Georgia, twenty of which are four-year public colleges with tuition charges and fees similar to UGA's. For HOPE Scholars seeking a degree at a one of these schools, the program covers tuition, HOPE-approved mandatory fees, and a book allowance. For the 2004-05 academic year, the award is worth over $\$ 4,500$ at UGA, accounting for more than 40 percent of the total cost of attendance. There is no time limit on a student's potential HOPE endowment, which can be spent on summer-school courses under exactly the same terms as the academic-year courses.

As summarized at the outset, an entering freshman is eligible for the scholarship if she graduated high school (since 1993) with at least a "B" average and is a Georgia resident. Students must maintain a 3.0 GPA in college to retain HOPE. A HOPE Scholar's GPA is checked three different times, corresponding to points when she has attempted enough credits to be a sophomore, junior and senior). During the sample period, UGA operated on the quarter system, so these checkpoints occurred at 45, 90, and 135 credit hours. If a student's GPA falls below 3.0, she loses the scholarship, but can re-establish eligibility at the next checkpoint if she raises her GPA back to the 3.0 threshold. Those who do not qualify for HOPE based on their highschool GPA can become eligible after 45 credit hours if their GPA is at least 
3.0 .

Table 2 summarizes the data on HOPE loss at each checkpoint for the first four post-HOPE entering classes. Two patterns stand out. First, virtually all of the scholarship loss occurs at the first checkpoint. This fact likely heightens students' sensitivity to the tradeoffs involved in course selection in the first year. Second, the percentage of students losing HOPE dropped steadily as the program matured and the income cap was removed. Over 50 percent of the original HOPE Scholars failed to retain their scholarships after the first checkpoint, while only about 33 percent of those who entered in 1996 lost their awards. Summing over all four classes, the loss rate was about 38 percent. ${ }^{7}$

\subsection{Retention Rules and Course Selection}

There are a number of responses that may account for the GPA gains of in-state students documented in Figure 1. Some, like increased effort and reduced work hours (due to the income effect associated with HOPE) are consistent with the goals of the program and enhance a student's human capital investment. Others, like the course-load adjustments examined by CLM, while unintended, have ambiguous effects on human capital acquisition. Here we consider two additional possibilities - course and major selection-which are also unintended, but whose human capital and earnings consequences are more clearly negative (as suggested by Hamermesh and Donald, 2003).

To examine the effects of HOPE on course selection, we focus on the courses that satisfy a student's general college core requirements, because they will weigh heavily in her schedule through the first two HOPE GPA checkpoints. These courses fall into one of the following three categories:

\footnotetext{
${ }^{7}$ HOPE loss also varies by race, gender, and high-school achievement. The loss rate for blacks is almost twice that of whites (61 versus 35 percent), and about 6 percentage points higher for men (42 versus 36 percent). On average, HOPE losers have lower HSGPAs (by .3 points) and SAT scores (by 30 points) and enter college with (3) fewer AP credits.
} 
Humanities and Fine Arts (Area I), Mathematics and Natural Sciences (Area II), and Social Sciences (Area III). Although there are certain courses that all undergraduate students at UGA are required to take (e.g., English Composition), students are generally allowed to choose from a list of the approved courses in each area. To satisfy the core requirements, a student must take at least four courses in each area. Table 3 provides a complete listing of these courses by area.

Table 4 gives the mean GPA and high-school achievement characteristics in each area, pre- and post-HOPE, for residents and non-residents. GPAs in Area II courses are substantially smaller than in Areas I and III during the pre-HOPE period for both residents and non-residents. If the lower GPAs in math and science courses signal a relatively high degree of difficulty for the typical student, then HOPE may induce a substitution away from such courses. The students who avoid or postpone Area II courses should be those with a lower chance of success, leaving behind a relatively better pool of enrollees. The pattern of relative improvement in the Area II resident GPA suggests this has occurred.

Our analysis of HOPE's influence on the choice of major aggregates individual majors into six distinct areas of study: (1) Fine Arts, Humanities and Social Sciences (AH\&SS), (2) Math and Sciences (M\&S), (3) Business, (4) Education, (5) "Other" (which includes Agricultural and Environmental Sciences, Family and Consumer Sciences, Forest Resources, Social Work, and Environmental Design), and (6) unspecified Arts and Sciences (unspecified A\&S). Table 5 reports the mean first-year GPA and high-school achievement characteristics, pre- and post-HOPE, for residents and non-residents, in $\mathrm{M} \& \mathrm{~S}$, Business, Education. In the pre-HOPE period, there is relatively little difference across majors in terms of students' first-year GPAs, despite Education majors having, on average, .10-.15-point lower HSGPAs and 80point lower SAT scores. Thus, if HOPE affects major choice at all, we expect 
it to push some students with relatively low-quality inputs into Education. Interestingly, there is considerable relative improvement in the high-school achievement characteristics of the typical Education major in the post-HOPE period, which is consistent with HOPE-induced sorting into Education.

Finally, some of these gains depicted in Figure 1 may be unrelated to behavior in college, and rather due to the selection of relatively better instate students in the admissions process. CLM investigate this possibility and find the evidence for relative quality changes confined largely to SAT verbal (SATV) scores. The estimated HOPE effect on SATV scores was statistically significant 9.3 points, while that pertaining to SAT math (SATM) scores was only 1.5 and statistically insignificant. They also report a significant HOPE effect for HSGPA of 0.065 , but point out that the eligibility rules create many of the same incentives as the retention rules, so it does not follow that the relative improvement in residents' high-school grades represents an increase in the relative quality of in-state students.

\section{Estimated Program Effects}

\subsection{General Empirical Strategy}

Our general empirical strategy is to contrast the outcomes or decisions of residents before and after HOPE with those of non-residents who constitute a control group. In each case, this amounts to estimating a regression model of the form

$$
y_{i t j}=\beta G A_{i} \cdot H_{t}+\alpha_{1} G A_{i}+\alpha_{2} H_{t}+\mathbf{X}_{i 1} \gamma_{1}+\mathbf{X}_{i 2} \gamma_{2}+H S_{j} \delta+\epsilon_{i t j},
$$

where $y_{i t j}$ is a outcome or behavioral response for student $i$ from high school $j$ in academic year $t$ (college GPA in this section); $H_{t}$ is a HOPE indicator that is set to 1 for students who matriculated in 1993 or later; $G A_{i}$ is a 
Georgia-resident dummy; $\mathbf{X}_{i 1}$ contains personal characteristics (race, gender and (matriculation) class-year); $\mathbf{X}_{i 2}$ includes high-school achievement variables (HSGPA, SATV and SATM scores, and AP credits); $H S_{j}$ indicates a graduate of high school $j$; and $\epsilon_{i t j}$ is the error term. The program effect is captured the coefficient of the interaction between the HOPE and Georgia-resident dummies.

The high-school dummies control for unobserved pre-college peer and school quality that may affect course-taking decisions in college. Using data similar to ours from the University of California-San Diego, Betts and Morrell (1999) show that adding high-school fixed effects to a college GPA regression with the same covariates as in $\mathbf{X}_{i 1}$ and $\mathbf{X}_{i 2}$ explains another 13 percent of the variation in college GPA. If college GPA is (partially) correlated with high school attended, then choices about course loads, which also affect college GPA, will be as well.

Table 6 presents the summary statistics for first-year college GPA and the high-school achievement variables used in our analysis, separately for residents and non-residents, in both the pre- and post-HOPE periods. The resident-non-resident contrasts in college GPA indicate about a .07 point average gain for in-state students relative to their out-of-state counterparts. Consistent with CLM, there are small differences in differences in HSGPA and SATV scores, and essentially none in SATM scores. The difference in differences in AP credits goes the other way, indicating that residents fell behind out-of-state students in this area of achievement after HOPE was introduced.

\subsection{Grade-Point Average}

In quantifying HOPE's effect on college GPA, we focus on the 1990 and 1995 classes depicted in Figure 1. This contrast compares the last cohort never to benefit from HOPE and the first cohort to have "full coverage", avoiding 
the problem of having non-qualifiers (due to the income cap) included in the treatment group.

\subsubsection{Freshman GPA}

We first estimate the effect of HOPE on freshmen GPA, which is the basis for retention at the first HOPE checkpoint. Beginning with the basic program effect without As a baseline, we begin with the simple program effect, and then incrementally add personal characteristics, high-school achievement, and high-school fixed effects. Table 7 presents the results of this analysis.

The baseline HOPE effect estimate is 0.148 (column (1)). Evaluated in terms of the pre-HOPE mean, this implies first-year resident GPAs were 5.8 percent higher because of HOPE. Controlling for gender and race increases the estimated HOPE effect to 0.176 (column (2)), but adding SAT scores, HSGPA, and AP credits drives it down 0.076 (column (4)). Including all of the covariates plus the high-school fixed effects raises the estimated program effect to 0.130 (column (5)), which is very close to the baseline estimate. In each case the estimated HOPE effect is significant at the 5-percent level.

The effects of the control variables are in line with the literature on the determinants of college GPA. It is noteworthy that the substantial differences in GPA for women and blacks shown in column (2) fall to one-third and onesixth of their values when the full specification is estimated, consistent with Betts and Morell (1999). Controlling for HSGPA, AP credits, and highschool fixed effects also dramatically reduces the importance of SAT scores. By comparison, the estimated HOPE coefficient in column (5) is roughly equivalent to three times the female effect, twice (in absolute value) the effect of being black, and a 100-point SAT score increase. Finally, column (5) indicates that 1-point rise in HSGPA increases college GPA by 0.722 points. 


\subsubsection{GPA Beyond the First Year}

Next we examine whether the HOPE-induced grade increases reported in Table 7 persist beyond the first year. Our sample allows us to follow the 1990 and 1995 classes through their third years at the university, so we reestimate (1) with second and third-year cumulative GPA as the regressand. Table 8 reports these results with the first-year findings from column (5) of Table 7.

The estimated HOPE effects on GPA are still positive in the second and third years, but smaller and not as precisely estimated. The program effect estimate on second-year GPA is 0.072 and 0.081 on third-year GPA, but neither is statistically at even the 10-percent level. Interestingly, the GPA differences between women and men and blacks and whites rise after the first year, while the influence of high-school achievement diminishes. By the third year, the degree to which women earn higher and blacks earn lower GPAs is roughly on par with the effect of the scholarship.

\subsection{Course Selection}

\subsubsection{Freshmen Core Courses}

As discussed in section 3.2, we concentrate on students' core course selections, because they will generally figure significantly in HOPE retention through the first two GPA checkpoints. Recall each of these courses falls into one of three curriculum areas: Area I-Humanities and Fine Arts, Area II-Mathematics and Natural Sciences, and Area III-Social Sciences (see Table 3) and a student must take at least four courses in each area to satisfy the core requirements.

Our course selection analysis involves estimating (1) with regressands credit hours enrolled, withdrawn, and completed in each of the curriculum areas, using the sample of students with no AP credits in these areas. These 
results are given in Table 9, with first three columns covering enrolled credits; the next three, withdrawn credits; and the last three, completed credits. Each set of three columns separately lists the estimates for Areas I, II, and III.

The estimated HOPE effects on enrolled credit hours suggest that the scholarship reduced enrollments in Area I and II courses and increased them in Area III courses. However, none of these program effects is very precisely estimated, all having $t$-ratios less than 1.45. The evidence for a HOPE effect on course withdrawals is also weak in Area I and III. In contrast, the data clearly indicate that the scholarship caused withdrawals to rise in math and science courses. The program effect estimate is 0.409 and statistically significant at the 1-percent level. This implies that HOPE has increased withdrawn credits in Area II by .41, which translates into about a 65 percent jump over the pre-HOPE mean.

Completed credit hours reflect the combination of enrollment and withdrawal decisions. These results are presented in the last three columns of Table 9. The largest and most precisely estimated HOPE effect is associated with Area II. The point estimate is -0.631 with a $t$ ratio of 2.2 , which implies that residents completed .63 fewer credits in math and science courses after 1993 because of HOPE. When evaluated in terms of the pre-HOPE mean, this translates into a 6 percent drop in completed Area II credits. This finding is consistent with the view that relatively low expected grades in Area II courses (see Table 4) induce a substitution away from math and science courses in the first year.

There is weaker evidence that HOPE has encouraged the same sort of behavior in AREA I courses. The estimated program effect is -0.573 , which is statistically significant at the 10-percent level. Given the relatively high GPAs in arts and humanities courses, this result is unexpected.

Finally, gender, race, and high-school achievement matter in course selection. Women complete significantly more credit hours in arts and human- 
ities, but fewer in math and sciences and social sciences. Both Asians and blacks complete fewer hours in arts and humanities and social sciences than do whites. The number of credit hours completed rises with HSGPA in all core-course areas. However, SATV and SATM scores have differing effects. Not surprisingly, students with higher SATM scores complete more credits in math and sciences but fewer in the other two areas, while those who have better SATV scores take fewer hours in the former but more in the latter.

\subsubsection{Core Courses After the First Year}

First-year students respond to the HOPE retention rules by completing fewer credit hours in the math and sciences core curriculum area. Do students just postpone taking certain courses to the second year or persistently avoid them? Following Hamermesh and Donald (2004), students who take more math and science courses earn more, so avoiding such courses is costly.

To address this question, we estimate HOPE's effects on credit hours enrolled, withdrawn, completed in each area during the second year. The results from this exercise are given the last three columns of Table 10. The first-year findings are repeated in the first three columns to facilitate interpretation ${ }^{8}$

Again, the data suggest HOPE reduced completed credit hours in Area II courses. Compared with the the first-year HOPE effect estimate, the estimated second-year program effect is only slightly smaller, -0.563 , but is less precise with a $t$-ratio of 1.6. Taken together, the first and second-year estimates suggest that residents completed about 1.2 fewer math and sciences credit hours during their first two years of college because of the scholarship. While it is possible that enrollment in these courses may be delayed even into the third or fourth year, this is unlikely given their prerequisite status for many majors.

\footnotetext{
${ }^{8}$ There are 22,802 first-year students with no AP credits in core curriculum areas. The number drops to 16,529 in the second year, because of attrition and the the students who matriculated in 1997 cannot be followed through their second year.
} 
The second-year results put some perspective on the fall in Area I credit hours implied by the first-year estimated HOPE effect. The second-year estimate is positive, larger in absolute value, and precise enough (0.600 with a $t$ ratio of 1.44) to suggest that students have intertemporally substituted arts and humanities courses from the first year to the next. The first-year credit-hour drop is consistent with the general incentive to forestall the first checkpoint by taking a lighter load.

\subsection{Major Choice}

Finally, we evaluate whether HOPE as influenced the choice of major. While, the labor-market consequences of this decision documented by Hamermesh and Donald (2004) make this behavioral response unlikely, the opportunity presented by certain majors for academic success given relatively low levels of high-school achievement may be compelling in the face of HOPE's retention rules.

To pursue this line of analysis, we re-specify (1) as a multinomial logit model with $y$ now taking a value of 1 to 6 indicating the student's declared major in her first year: 1, if Fine Arts, Humanities and Social Sciences (AH\&SS); 2, if Math and Sciences; 3, if Business; 4, if Education; 5, if Other; and 6, if unspecified Arts and Sciences. ${ }^{9}$ Another change in the specification is that we no longer include high-school fixed effects, because of the complexity they add to estimation. Instead, we insert the weights constructed by the Admissions Office to take into account high-school quality. The difference is that the weights are the same for groups of high schools of comparable quality, so each high-school no longer serves as its own control.

Table 11 reports the multinomial logit coefficient estimates where the baseline category is unspecified Arts and Sciences. While these are difficult to interpret, none of the estimated $G A \cdot H$ coefficients are statistically significant.

\footnotetext{
${ }^{9}$ By combining majors into these broader fields, we make estimation empirically tractable and reduce the "independence of irrelevant alternatives" problem.
} 
However, declared major does appear to vary with personal characteristics and high-school achievement.

What we care about are the partial effects of the explanatory variables on the probability of choosing a particular major. In the case of the continuous variables, this involves the usual partial derivative. The partial effects of the discrete regressors on choosing major $k$ are computed as

$$
\left(P_{11}^{k}-P_{10}^{k}\right)-\left(P_{01}^{k}-P_{00}^{k}\right)
$$

where $P_{m n}^{k}=\operatorname{Pr}\left(y_{i t}=k \mid H_{t}=m, G A_{i}=n\right)$. Table 12 reports the estimated partial effects associated with the program variable $G A \cdot H$. The top row lists the program effect estimates for the average student, that is, (2) calculated at the mean values of the explanatory variables. In the other rows, we provide the estimated HOPE effects by gender and race.

The HOPE effect estimates are small and statistically insignificant for every major except Education and Business (columns (4) and (3)). In the case of Education, we find that HOPE raised the probability that the average resident declared this field of study by 1.2 percentage points. The result is significant at the 5-percent level. The influence of HOPE on the decisions of women and whites is greater than for the typical student. Resident women are about 2 percentage points more likely to major in education than their out-of-state counterparts, because of the scholarship; whites are 1.3 percentage points more likely. Both of these estimates are statistically significant at close to the 5-percent level.

Although not significant at conventional levels, the program effect estimates for the Business major suggest HOPE lowered the probability that a typical resident chose to concentrate her studies in this area. For the average student, the scholarship effect is 1.7 percentage points. The results indicate slightly larger responses by men and whites.

Overall, our findings concerning the impact of HOPE on declared majors 
imply that there has been some substitution away from other majors, most notably Business, to Education. The effects are not large -1 percent of resident freshman amounts to about 35-40 students - but as we have argued, they are potentially costly because earnings are so closely tied to a student's college major.

\section{Conclusion}

Since the introduction of Georgia's HOPE Scholarship in 1993, there has been a proliferation of state-sponsored merit scholarships, justified in part by the incentive they create for academic achievement and human capital investment. While their GPA requirements for eligibility and retention encourage greater effort, they also create a payoff to other grade-enhancing behaviors. Two that have not been examined are choosing certain courses and declaring a particular major because the expected grades therein are higher. Our interest in these responses relates to their labor-market consequences as documented by Hamermesh and Donald (2004).

So, in this paper, we focus on the HOPE Scholarship and its influence on grades in college, course selection, and major choice. Using data on the undergraduates who enrolled at the University of Georgia between 1989 and 1997, we estimated the effects of the scholarship on cumulative GPA in the first, second, and third years; completed credit hours in core curriculum courses during the first two years; and the major declared in the first year. The basic empirical strategy is to treat non-resident students, who are not eligible for HOPE, as a control group.

First, we find that the GPAs of resident freshmen rose almost .13 points (or 5 percent) because of HOPE, and effect comparable in magnitude to a 100-point SAT score increase. Although the estimated effect of the scholarship on GPA beyond the first year remained positive, it was half the size and imprecisely estimated. Second, we show that HOPE reduced the num- 
ber of credit hours in math and science core curriculum courses completed by residents during their first year. This result was repeated for the second year, suggesting that residents were not merely postponing math and science courses, but perhaps avoiding them entirely. The combination of both years' responses implies that residents completed about 1.2 fewer math and sciences credit hours because of HOPE. Finally, the probability of choosing an Education jumped 1.2 percentage points for residents relative to their out-of-state counterparts after HOPE was introduced, with the scholarship's influence on this decision being more pronounced for women and whites.

The extent to which these results can be generalized to other statesponsored merit scholarships depends on how "HOPE-like" they are. At least two characteristics of Georgia's program are key in this regard. First, the award retained solely through meeting a specified grade-based criteria. Second, there is no fixed time period (e.g., eight semesters) for scholarship qualifiers to use their awards. Many of programs started in the mid-1990s have these characteristics, although the newest of the scholarships have limits on the number of semesters or academic years they can be used. 


\section{References}

[1] Betts, Julian R. and Darlene Morell (1999), The Determinants of Undergraduate Grade Point Average: The Relative Importance of Family Background, High School Resources, and Peer Group Effects, The Journal of Human Resources, 34(2), 268-293.

[2] Bugler, Daniel T., Gary T. Henry and Ross Rubenstein (1999), An Evaluation of Georgia's HOPE Scholarship Program: Effects of HOPE on Grade Inflation, Academic Performance and College Enrollment, Council for School Performance, Georgia State University, Atlanta, GA.

[3] Cornwell, Christopher M., Kyung Hee Lee and David B. Mustard (2005), Student Responses to Merit Scholarship Retentions Rules, Journal of Human Resources, forthcoming.

[4] Cornwell, Christopher M., Mark Leidner and David B. Mustard (2004), Rules, Incentives and Policy Implications of Large-Scale Merit-Based Financial Aid Programs, University of Georgia Department of Economics Working Paper, Athens, GA.

[5] Cornwell, Christopher M. and David B. Mustard (2005), Merit-Based College Scholarships and Car Sales, University of Georgia Department of Economics Working Paper, Athens, GA.

[6] Cornwell, Christopher M., David B. Mustard and Deepa J. Sridhar (2004), The Enrollment Effects of Merit-based Financial Aid: Evidence from Georgia's HOPE Scholarship, University of Georgia Department of Economics Working Paper, Athens, GA.

[7] Dee, Thomas S. and Linda A. Jackson (1999), Who Loses HOPE? Attrition from Georgia's College Scholarship Program, Southern Economic Journal, 66(2), 379-390. 
[8] Hamermesh, Daniel S. and Stephen G. Donald (2003), The Effect of College Curriculum on Earnings: Accounting for Non-Ignorable NonResponse Bias, Unpublished Paper, University of Texas, Austin, TX.

[9] Henry, Gary T. and Ross Rubenstein (2002), Paying for Grades: Impact of Merit-Based Financial Aid on Educational Quality, Journal of Policy Analysis and Management, 21(1), 93-109.

[10] Henry, Gary T., Ross Rubenstein and Daniel T. Bugler (2002), Is HOPE Enough? Impacts of Receiving and Losing the HOPE Scholarship, Manuscript Submitted for Publication, Georgia State University, Atlanta, GA.

[11] Heather Rose and Julian R. Betts (2004), The Effect of High School Courses on Earnings, The Review of Economics and Statistics, 86(2), 497-513.

[12] Sridhar, Deepa J. (2001), Postsecondary Enrollment Effects of MeritBased Financial Aid: Evidence from Georgia's HOPE Scholarship Program, Ph.D. Dissertation, University of Georgia, Athens, GA. 
Figure 1 Cumulative GPA Distributions of Typical First-Year Students, Residents vs. Non-residents, 1990-95 Classes

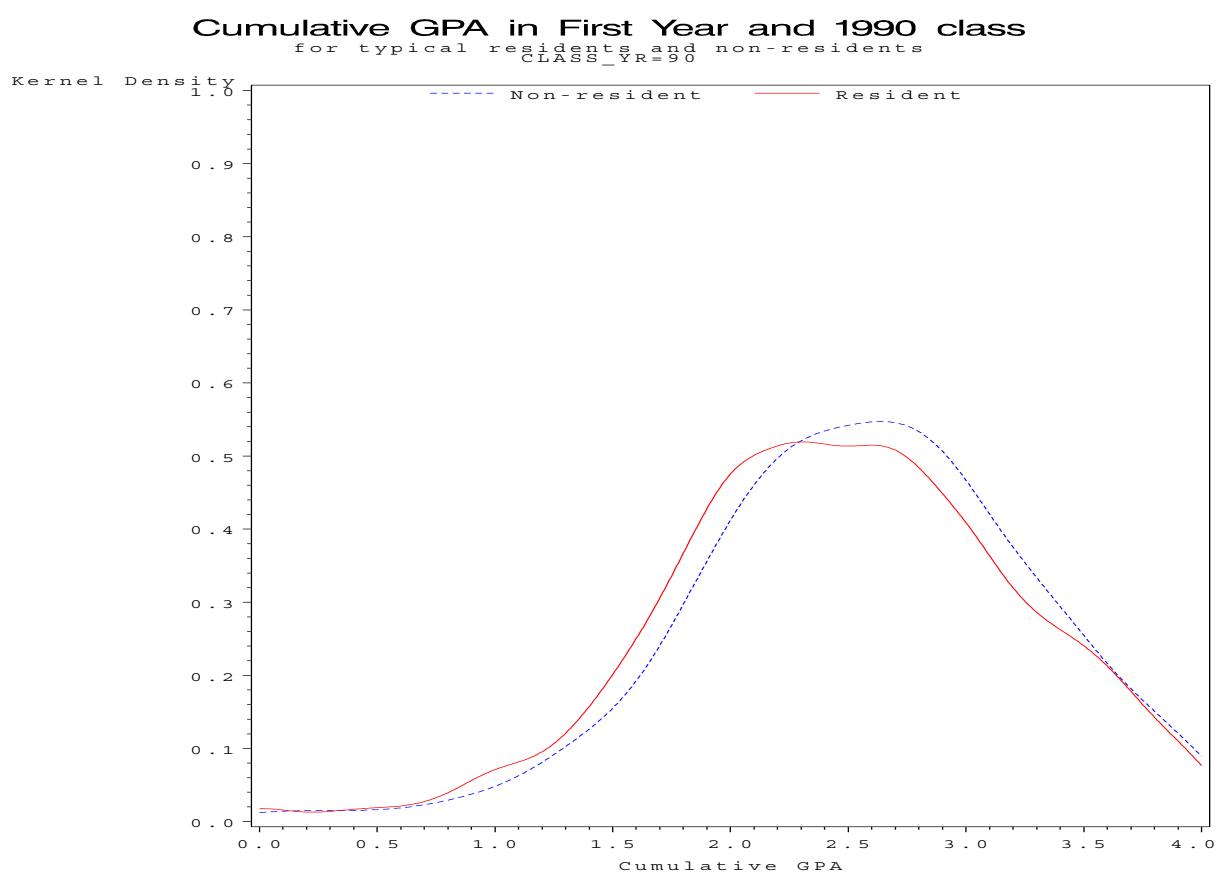

(a) Pre-HOPE: 1990 Class

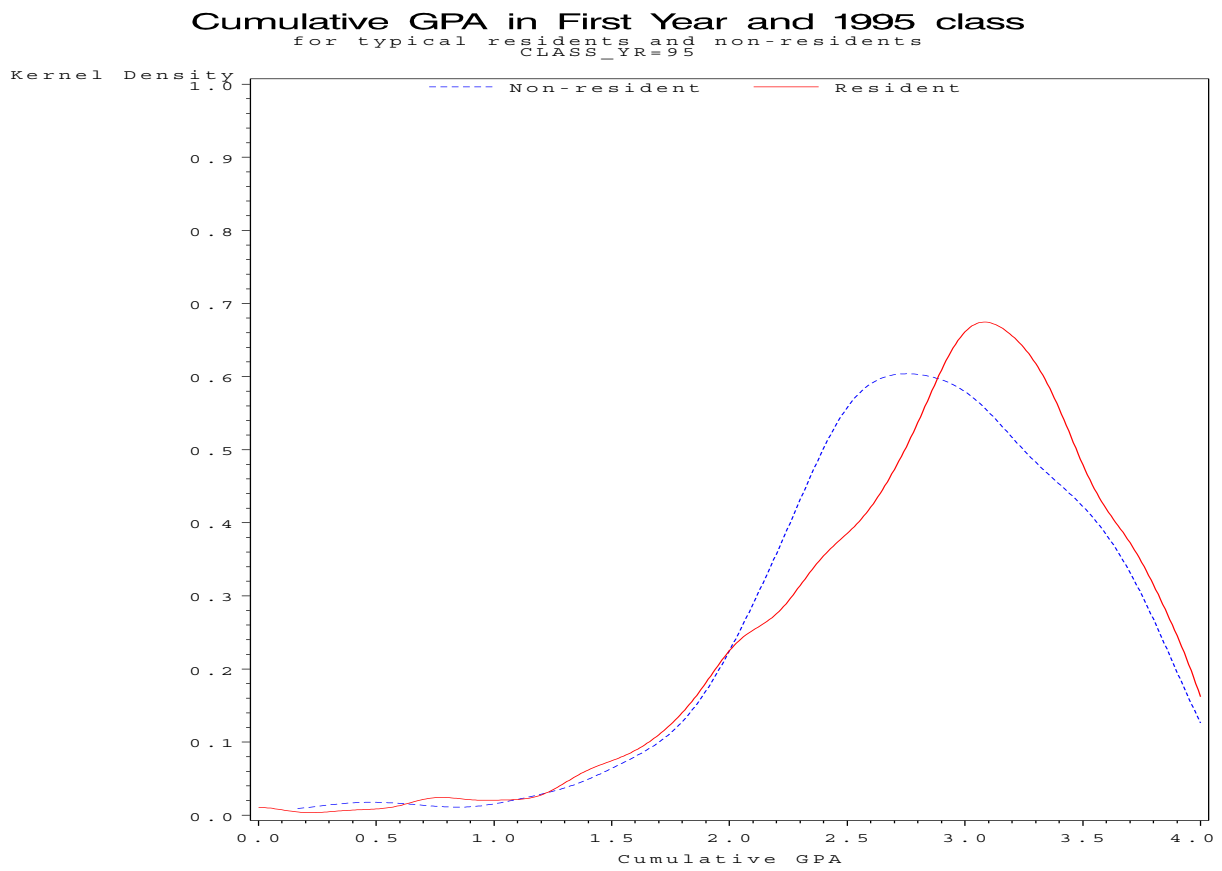

(b) Post-HOPE: 1995 Class 


\section{Table 1}

Number and Percentage of Typical FTF Georgia Residents Who Are Admitted as HOPE Scholars

\begin{tabular}{cccc}
\hline Class Year & TFTF & TFTF GA-Residents & TFTF HOPE Scholars \\
$N$ & $3, \%)^{a}$ & $0(0.00)$ \\
\hline \hline 1989 & 3,441 & $2,923(84.95)$ & $0(0.00)$ \\
1990 & 3,432 & $2,887(84.12)$ & $0(0.00)$ \\
1991 & 3,042 & $2,598(85.40)$ & $0(0.00)$ \\
1992 & 3,092 & $2,610(84.41)$ & $949(35.21)$ \\
1993 & 3,264 & $2,695(82.57)$ & $2,284(75.48)$ \\
1994 & 3,521 & $3,026(85.94)$ & $2,963(94.57)$ \\
1995 & 3,651 & $3,133(85.81)$ & $3,034(96.16)$ \\
1996 & 3,510 & $3,155(89.89)$ & $3,608(97.43)$ \\
1997 & 4,165 & $3,703(88.91)$ & 0 \\
\hline Mean & & & $2,568(81.73)$ \\
\hline Pre-HOPE (89-92) & 3,252 & $2,755(84.72)$ & $12,838(48.03)$ \\
\hline Total & 3,622 & $3,142(86.75)$ & \\
\hline
\end{tabular}

${ }^{a}$ Percent of typical FTF who are Georgia residents.

${ }^{b}$ Percent of typical FTF Georgia residents who are admitted as HOPE Scholars. 
Table 2

Number and Percentage of Typical FTF HOPE Scholars ${ }^{a}$

Who Lose Their HOPE Awards at Each Checkpoint ${ }^{b}$

\begin{tabular}{ccccc}
\hline \multirow{2}{*}{ Class Year } & TFTF & \multicolumn{3}{c}{ TFTF HOPE Losers } \\
\cline { 3 - 5 } & HOPE Scholars & First Check & Second Check \\
$N$ & $N(\%)^{c}$ & $\begin{array}{c}\text { Third Check } \\
N(\%)^{c}\end{array}$ & $N(\%)^{c}$ \\
\hline \hline 1993 & 949 & $479(50.47)$ & $58(6.11)$ & $16(1.69)$ \\
1994 & 2,284 & $983(43.04)$ & $145(6.35)$ & $47(2.06)$ \\
1995 & 2,968 & $1,134(38.21)$ & $145(4.89)$ & $\mathrm{N} / \mathrm{A}$ \\
1996 & 3,034 & $990(32.64)$ & $\mathrm{N} / \mathrm{A}$ & $\mathrm{N} / \mathrm{A}$ \\
\hline \multirow{2}{*}{ Mean } & 2,309 & $897(38.85)$ & $116(5.02)$ & $32(1.39)$ \\
Total & 9,235 & $3,586(38.83)$ & $348(3.77)$ & $63(0.68)$ \\
\hline \hline
\end{tabular}

${ }^{a}$ Typical FTF who are admitted as HOPE Scholars.

${ }^{b}$ During our sample period the three checkpoints are 45, 90, and 135 credit hours.

${ }^{c}$ Percent of typical FTF HOPE Scholars who lose their scholarship at each checkpoint. 
Table 3

General Core Courses at The University of Georgia

\begin{tabular}{lll}
\hline AREA & Course ID & \\
\hline \hline 1 & ART200 & Appreciation of the Visual Arts \\
1 & ART287 & Introduction to the History of Ancient and Medieval Art \\
1 & ART288 & Introduction to the History of Art Renaissance-18th Century \\
1 & ART289 & Introduction to 19th and 20th Century Art \\
1 & CLC120 & Classical Culture: Greece \\
1 & CLC121 & Classical Culture: Rome \\
1 & CLC150 & Mythology in Classical Literature \\
1 & CML221 & Western World Literature \\
1 & CML222 & Western World Literature \\
1 & DRA200 & Appreciation of Theatre \\
1 & DRA212 & Introduction to Cinema \\
1 & ENG101 & English Composition \\
1 & ENG102 & English Composition \\
1 & ENG231G & Masterpiece of English Literature to 1700 \\
1 & ENG232G & Masterpiece of English Literature after 1700 \\
1 & ENG233G & Masterpiece of American Literature \\
1 & FR 101 & Elementary French \\
1 & FR 102 & Elementary French \\
1 & FR 103 & Elementary French \\
1 & FR 201 & Intermediate French \\
1 & FR 202 & Intermediate French \\
1 & FR 202B & Intermediate French \\
1 & GER101 & Elementary German \\
1 & GER102 & Elementary German \\
1 & GER103 & Intermediate German \\
1 & GER221 & Intermediate German \\
1 & ITA101 & Elementary Italian \\
1 & ITA102 & Elementary Italian \\
1 & ITA103 & Elementary Italian \\
1 & ITA201 & Intermediate Italian \\
\hline \hline & &
\end{tabular}

Continued 
Table 3 (Continued), General Core Courses at The University of Georgia

\begin{tabular}{|c|c|c|}
\hline AREA & Course ID & Course Title \\
\hline 1 & LAT101 & Elementary Latin I \\
\hline 1 & LAT102 & Elementary Latin II \\
\hline 1 & LAT103 & Elementary Latin III \\
\hline 1 & MUS202 & Appreciation of Music \\
\hline 1 & PHY100 & Survey of Philosophy \\
\hline 1 & PHY101 & Introduction to Philosophical Issues \\
\hline 1 & PHY102 & Logic and Critical Thinking \\
\hline 1 & REL115 & Introduction to Western Religious Traditions \\
\hline 1 & REL116 & Introduction to the Major Religious Perspectives of Mankind \\
\hline 1 & RUS101 & Elementary Russian \\
\hline 1 & RUS102 & Elementary Russian \\
\hline 1 & RUS103 & Intermediate Russian \\
\hline 1 & SP 101 & Elementary Spanish \\
\hline 1 & SP 102 & Elementary Spanish \\
\hline 1 & SP 103 & Elementary Spanish \\
\hline 1 & SP 201 & Intermediate Spanish \\
\hline 1 & SP 202 & Intermediate Spanish \\
\hline 1 & SPC108 & Fundamentals of Speech Communication \\
\hline 1 & SPC256 & Introduction to Small Group Communication \\
\hline 2 & AST107 & Introduction to Astronomy \\
\hline 2 & AST108 & Introduction to Astronomy \\
\hline 2 & AST291 & Descriptive Astronomy \\
\hline 2 & BIO101 & Principles of Biology (offered in $1989 \& 90$ and continued as BIO103) \\
\hline 2 & BIO102 & Principles of Biology (offered in $1989 \& 90$ and continued as BIO104) \\
\hline 2 & BIO103 & Principles of Biology \\
\hline 2 & $\mathrm{BIO} 104$ & Principles of Biology \\
\hline 2 & $\mathrm{BIO} 107$ & General Biology \\
\hline 2 & $\mathrm{BIO} 108$ & General Biology \\
\hline 2 & BOT121 & Elementary Botany \\
\hline 2 & BOT122 & Elementary Botany \\
\hline
\end{tabular}

Continued 
Table 1 (Continued), General Core Courses at The University of Georgia

\begin{tabular}{|c|c|c|}
\hline AREA & Course ID & Course Title \\
\hline 2 & CHM111 & Elementary Chemistry \\
\hline 2 & CHM112 & Elementary Chemistry \\
\hline 2 & CHM121 & General Chemistry \\
\hline 2 & CHM122 & General Chemistry \\
\hline 2 & CS 101 & Introduction to Information Processing and Microcomputers \\
\hline 2 & CS 201 & Introduction to Computing \\
\hline 2 & GGY104 & Earth Science Survey \\
\hline 2 & GGY120 & Introductory Weather and Climate \\
\hline 2 & GGY121 & Introduction to Landforms \\
\hline 2 & GGY122 & Introduction to Bio and Soil Geography \\
\hline 2 & GLY115 & Earth Processes and Environments \\
\hline 2 & GLY116 & The Earth Through Time \\
\hline 2 & GLY125 & Physical Geology \\
\hline 2 & GLY126 & Historical Geology \\
\hline 2 & MAT102 & College Algebra \\
\hline 2 & MAT105 & Introduction to Mathematics \\
\hline 2 & MAT106 & Introduction to Mathematics II \\
\hline 2 & MAT109 & Trigonometry \\
\hline 2 & MAT116 & Precalculus Mathematics \\
\hline 2 & MAT205 & Mathematics for Elementary Teachers \\
\hline 2 & MAT206 & Mathematics for Elementary Teachers \\
\hline 2 & MAT253 & Analytic Geometry and Calculus \\
\hline 2 & PCS101 & Physical Science \\
\hline 2 & PCS127 & Introductory Physics - Mechanics \\
\hline 2 & PCS128 & Introductory Physics - Thermodynamics, Electricity and Magnetism \\
\hline 2 & PCS137 & Introductory Physics for Science and Engineering Students - Mechanics \\
\hline 2 & PCS138 & $\begin{array}{l}\text { Introductory Physics for Science and Engineering Students } \\
\text { - Thermodynamics, Electricity and Magnetism }\end{array}$ \\
\hline 2 & PHY110 & Symbolic Logic \\
\hline 2 & STA200 & Elementary Statistics \\
\hline 2 & STA221 & Introduction to Statistics and Programming \\
\hline 2 & STA222 & Introduction to Statistics and Programming II \\
\hline
\end{tabular}

Continued 
Table 3 (Continued), General Core Courses at The University of Georgia

\begin{tabular}{lll}
\hline AREA & Course ID & \multicolumn{1}{c}{ Course Title } \\
\hline \hline 2 & ZOO212 & Human Anatomy \\
2 & ZOO213 & Human Physiology \\
3 & ANT102 & Introduction to Anthropology \\
3 & ECN106 & Principles of Microeconomics \\
3 & ECN107 & Principles of Macroeconomics \\
3 & GGY101 & Introduction to Human Geography \\
3 & HIS111 & History of Western Civilization to 1500 \\
3 & HIS112 & History of Western Civilization Since 1500 \\
3 & HIS121 & Early Modern Western Civilization \\
3 & HIS122 & Modern Western Civilization \\
3 & HIS251 & American History to 1865 \\
3 & HIS252 & American History Since 1865 \\
3 & LIN210 & The Study of Language \\
3 & POL101 & American Government \\
3 & POL202 & Introduction to Political Science \\
3 & POL203 & Introduction to Global Studies \\
3 & PSY101 & Elementary Psychology \\
3 & PSY251 & Brain and Behavior \\
3 & PSY253 & Mental Processes \\
3 & PSY257 & Applications of Psychology \\
3 & SOC105 & Introductory Sociology \\
3 & SOC160 & Contemporary Social Problems \\
3 & SOS104 & Contemporary Georgia \\
\hline \hline
\end{tabular}


Table 4

Mean Grade Point, HSGPA and SAT Scores in Core Curriculum Areas Typical Resident vs. Non-resident Students ${ }^{a}$, 1989-97 Classes (Standard Deviations in Parentheses)

\begin{tabular}{|c|c|c|c|c|}
\hline \multirow[b]{2}{*}{ Variable } & \multicolumn{2}{|c|}{ Pre-HOPE (1989-92) } & \multicolumn{2}{|c|}{ Post-HOPE (1993-97) } \\
\hline & Non-resident & Resident & Non-resident & Resident \\
\hline \multicolumn{5}{|l|}{ AREA I: Arts \& Humanities } \\
\hline Grade-Point Average & $\begin{array}{c}2.89 \\
(0.88)\end{array}$ & $\begin{array}{c}2.85 \\
(0.89)\end{array}$ & $\begin{array}{c}3.01 \\
(0.88)\end{array}$ & $\begin{array}{c}3.03 \\
(0.89)\end{array}$ \\
\hline High-School GPA & $\begin{array}{c}2.98 \\
(0.44)\end{array}$ & $\begin{array}{c}3.09 \\
(0.51)\end{array}$ & $\begin{array}{c}3.12 \\
(0.44)\end{array}$ & $\begin{array}{c}3.31 \\
(0.45)\end{array}$ \\
\hline SAT Verbal Score & $\begin{array}{l}576.73 \\
(72.66)\end{array}$ & $\begin{array}{l}569.97 \\
(76.10)\end{array}$ & $\begin{array}{l}591.23 \\
(70.98)\end{array}$ & $\begin{array}{l}587.45 \\
(72.56)\end{array}$ \\
\hline SAT Math Score & $\begin{array}{l}561.36 \\
(61.80)\end{array}$ & $\begin{array}{l}558.08 \\
(66.83)\end{array}$ & $\begin{array}{l}577.44 \\
(63.49)\end{array}$ & $\begin{array}{l}576.13 \\
(68.47)\end{array}$ \\
\hline \multicolumn{5}{|l|}{ AREA II: Math \& Sciences } \\
\hline Grade-Point Average & $\begin{array}{c}2.42 \\
(1.17)\end{array}$ & $\begin{array}{c}2.40 \\
(1.17)\end{array}$ & $\begin{array}{c}2.58 \\
(1.09)\end{array}$ & $\begin{array}{c}2.66 \\
(1.10)\end{array}$ \\
\hline High-School GPA & $\begin{array}{c}3.01 \\
(0.45)\end{array}$ & $\begin{array}{c}3.13 \\
(0.50)\end{array}$ & $\begin{array}{c}3.14 \\
(0.45)\end{array}$ & $\begin{array}{c}3.33 \\
(0.45)\end{array}$ \\
\hline SAT Verbal Score & $\begin{array}{l}572.11 \\
(73.93)\end{array}$ & $\begin{array}{l}564.50 \\
(74.35)\end{array}$ & $\begin{array}{c}586.78 \\
(70.80)\end{array}$ & $\begin{array}{l}581.62 \\
(71.12)\end{array}$ \\
\hline SAT Math Score & $\begin{array}{l}569.41 \\
(63.02)\end{array}$ & $\begin{array}{l}562.96 \\
(65.85)\end{array}$ & $\begin{array}{l}579.09 \\
(63.22)\end{array}$ & $\begin{array}{l}576.80 \\
(67.62)\end{array}$ \\
\hline \multicolumn{5}{|l|}{ AREA III: Social Sciences } \\
\hline Grade-Point Average & $\begin{array}{c}2.60 \\
(0.95)\end{array}$ & $\begin{array}{c}2.55 \\
(0.99)\end{array}$ & $\begin{array}{c}2.76 \\
(0.95)\end{array}$ & $\begin{array}{c}2.79 \\
(0.97)\end{array}$ \\
\hline High-School GPA & $\begin{array}{c}2.97 \\
(0.43)\end{array}$ & $\begin{array}{c}3.07 \\
(0.50)\end{array}$ & $\begin{array}{c}3.12 \\
(0.43)\end{array}$ & $\begin{array}{c}3.32 \\
(0.44)\end{array}$ \\
\hline SAT Verbal Score & $\begin{array}{l}570.85 \\
(70.82)\end{array}$ & $\begin{array}{l}561.31 \\
(71.75)\end{array}$ & $\begin{array}{l}586.50 \\
(70.16)\end{array}$ & $\begin{array}{l}580.90 \\
(69.38)\end{array}$ \\
\hline SAT Math Score & $\begin{array}{l}562.61 \\
(61.17)\end{array}$ & $\begin{array}{l}555.52 \\
(64.25)\end{array}$ & $\begin{array}{l}577.28 \\
(63.51)\end{array}$ & $\begin{array}{l}574.60 \\
(66.80)\end{array}$ \\
\hline
\end{tabular}

a "Typical students" refers to those who matriculate at UGA in the fall term of the same year as they graduate from high school. 
Table 5

Mean Cumulative GPA, HSGPA and SAT Scores in Selected Majors Typical First-Year Students ${ }^{a}, 1989-97$ Classes (Standard Deviations in Parentheses)

\begin{tabular}{|c|c|c|c|c|}
\hline \multirow[b]{2}{*}{ Variable } & \multicolumn{2}{|c|}{ Pre-HOPE (1989-92) } & \multicolumn{2}{|c|}{ Post-HOPE (1993-97) } \\
\hline & Non-resident & Resident & Non-resident & Resident \\
\hline \multicolumn{5}{|l|}{ Math \& Science Majors } \\
\hline Cumulative GPA & $\begin{array}{c}2.67 \\
(0.85)\end{array}$ & $\begin{array}{c}2.64 \\
(0.75)\end{array}$ & $\begin{array}{c}2.91 \\
(0.67)\end{array}$ & $\begin{array}{c}2.84 \\
(0.76)\end{array}$ \\
\hline High-School GPA & $\begin{array}{c}3.21 \\
(0.47)\end{array}$ & $\begin{array}{c}3.29 \\
(0.47)\end{array}$ & $\begin{array}{c}3.37 \\
(0.43)\end{array}$ & $\begin{array}{c}3.49 \\
(0.41)\end{array}$ \\
\hline SAT Verbal Score & $\begin{array}{l}581.87 \\
(78.30)\end{array}$ & $\begin{array}{l}575.97 \\
(76.75)\end{array}$ & $\begin{array}{l}604.84 \\
(73.18)\end{array}$ & $\begin{array}{l}591.00 \\
(74.27)\end{array}$ \\
\hline SAT Math Score & $\begin{array}{l}595.61 \\
(64.38)\end{array}$ & $\begin{array}{l}582.57 \\
(68.96)\end{array}$ & $\begin{array}{l}610.00 \\
(70.32)\end{array}$ & $\begin{array}{c}602.08 \\
(74.99)\end{array}$ \\
\hline \multicolumn{5}{|l|}{ Business Major } \\
\hline$\overline{\text { Cumulative GPA }}$ & $\begin{array}{c}2.66 \\
(0.61)\end{array}$ & $\begin{array}{c}2.70 \\
(0.63)\end{array}$ & $\begin{array}{c}2.82 \\
(0.59)\end{array}$ & $\begin{array}{c}2.88 \\
(0.65)\end{array}$ \\
\hline High-School GPA & $\begin{array}{c}3.15 \\
(0.42)\end{array}$ & $\begin{array}{c}3.28 \\
(0.43)\end{array}$ & $\begin{array}{c}3.28 \\
(0.38)\end{array}$ & $\begin{array}{c}3.44 \\
(0.37)\end{array}$ \\
\hline SAT Verbal Score & $\begin{array}{l}576.55 \\
(59.80)\end{array}$ & $\begin{array}{l}578.15 \\
(62.96)\end{array}$ & $\begin{array}{l}593.50 \\
(57.47)\end{array}$ & $\begin{array}{l}585.03 \\
(60.91)\end{array}$ \\
\hline SAT Math Score & $\begin{array}{l}593.11 \\
(55.97)\end{array}$ & $\begin{array}{l}587.17 \\
(62.28)\end{array}$ & $\begin{array}{l}606.48 \\
(56.61)\end{array}$ & $\begin{array}{l}599.92 \\
(63.31)\end{array}$ \\
\hline \multicolumn{5}{|l|}{$\underline{\text { Education Major }}$} \\
\hline$\overline{\text { Cumulative GPA }}$ & $\begin{array}{c}2.66 \\
(0.55)\end{array}$ & $\begin{array}{c}2.59 \\
(0.68)\end{array}$ & $\begin{array}{c}2.77 \\
(0.64)\end{array}$ & $\begin{array}{c}2.88 \\
(0.69)\end{array}$ \\
\hline High-School GPA & $\begin{array}{c}3.04 \\
(0.43)\end{array}$ & $\begin{array}{c}3.15 \\
(0.48)\end{array}$ & $\begin{array}{c}3.18 \\
(0.45)\end{array}$ & $\begin{array}{c}3.42 \\
(0.40)\end{array}$ \\
\hline SAT Verbal Score & $\begin{array}{l}558.70 \\
(69.65)\end{array}$ & $\begin{array}{l}550.00 \\
(69.13)\end{array}$ & $\begin{array}{l}560.51 \\
(68.19)\end{array}$ & $\begin{array}{l}572.37 \\
(63.35)\end{array}$ \\
\hline SAT Math Score & $\begin{array}{l}548.62 \\
(55.79)\end{array}$ & $\begin{array}{l}536.53 \\
(61.14)\end{array}$ & $\begin{array}{l}562.43 \\
(62.52)\end{array}$ & $\begin{array}{l}560.23 \\
(63.06)\end{array}$ \\
\hline
\end{tabular}

a "Typical students" refers to those who matriculate at UGA in the fall term of the same year as they graduate from high school. 


\section{Table 6}

Sample Means and Percentages for Typical First-Year Students (standard deviations in parentheses)

\begin{tabular}{l|c|c|c|c}
\hline \multirow{2}{*}{ Variable } & \multicolumn{2}{|c|}{ Pre-HOPE $(1989-92)$} & \multicolumn{2}{c}{ Post-HOPE (1993-97) } \\
\cline { 2 - 5 } & Non-resident & Resident & Non-resident & Resident \\
\hline \hline \multirow{2}{*}{ Cumulative Grade Point Average } & \\
& & & & \\
High School GPA & 2.62 & 2.57 & 2.83 & 2.85 \\
& $(0.70)$ & $(0.72)$ & $(0.65)$ & $(0.70)$ \\
SAT Math Score & 3.05 & 3.23 & 3.26 & 3.47 \\
& $(0.45)$ & $(0.49)$ & $(0.43)$ & $(0.41)$ \\
SAT Verbal Score & 564.51 & 559.78 & 585.17 & 582.40 \\
SAT Total Score & $(64.06)$ & $(67.93)$ & $(65.80)$ & $(69.38)$ \\
& 574.01 & 565.92 & 592.70 & 589.22 \\
AP Credit Hours Taken & $(73.63)$ & $(77.26)$ & $(73.21)$ & $(71.74)$ \\
& 1138.52 & 1125.70 & 1177.88 & 1171.62 \\
& $(113.63)$ & $(124.78)$ & $(117.89)$ & $(120.98)$ \\
\hline \hline
\end{tabular}

${ }^{a}$ Percentage of typical first-year students enrolling in a full-credit load.

${ }^{b}$ Percentage of typical first-year students withdrawing from a class.

${ }^{c}$ Percentage of typical first-year students completing a full-credit load. 
Table 7

Estimated HOPE Effect on Cumulative GPA ${ }^{a}$

Typical First-Year Students ${ }^{b}, 1990$ and 95 Classes

(Robust Standard Errors in Parentheses)

\begin{tabular}{|c|c|c|c|c|c|}
\hline Variables & $(1)$ & $(2)$ & $(3)$ & $(4)$ & $(5)$ \\
\hline$G A \cdot H$ & $\begin{array}{c}0.148 \\
(0.045)\end{array}$ & $\begin{array}{c}0.176 \\
(0.044)\end{array}$ & $\begin{array}{c}0.115 \\
(0.043)\end{array}$ & $\begin{array}{c}0.076 \\
(0.039)\end{array}$ & $\begin{array}{c}0.130 \\
(0.057)\end{array}$ \\
\hline$H_{95}$ & $\begin{array}{c}0.272 \\
(0.041)\end{array}$ & $\begin{array}{c}0.259 \\
(0.041)\end{array}$ & $\begin{array}{c}0.129 \\
(0.041)\end{array}$ & $\begin{array}{c}0.022 \\
(0.037)\end{array}$ & $\begin{array}{l}-0.065 \\
(0.055)\end{array}$ \\
\hline$G A$ & $\begin{array}{l}-0.088 \\
(0.033)\end{array}$ & $\begin{array}{l}-0.065 \\
(0.033)\end{array}$ & $\begin{array}{l}-0.029 \\
(0.032)\end{array}$ & $\begin{array}{l}-0.119 \\
(0.029)\end{array}$ & $\begin{array}{l}-0.150 \\
(0.076)\end{array}$ \\
\hline$F E M A L E$ & & $\begin{array}{c}0.165 \\
(0.017)\end{array}$ & $\begin{array}{c}0.244 \\
(0.016)\end{array}$ & $\begin{array}{c}0.081 \\
(0.015)\end{array}$ & $\begin{array}{c}0.045 \\
(0.016)\end{array}$ \\
\hline$A S I A N$ & & $\begin{array}{c}0.091 \\
(0.052)\end{array}$ & $\begin{array}{c}0.099 \\
(0.047)\end{array}$ & $\begin{array}{c}0.003 \\
(0.038)\end{array}$ & $\begin{array}{l}-0.021 \\
(0.043)\end{array}$ \\
\hline$B L A C K$ & & $\begin{array}{l}-0.477 \\
(0.027)\end{array}$ & $\begin{array}{l}-0.145 \\
(0.028)\end{array}$ & $\begin{array}{l}-0.166 \\
(0.027)\end{array}$ & $\begin{array}{l}-0.074 \\
(0.035)\end{array}$ \\
\hline$H I S P N$ & & $\begin{array}{c}-0.139 \\
(0.100)\end{array}$ & $\begin{array}{c}-0.037 \\
(0.094)\end{array}$ & $\begin{array}{c}-0.115 \\
(0.089)\end{array}$ & $\begin{array}{l}-0.162 \\
(0.097)\end{array}$ \\
\hline OTHER & & $\begin{array}{l}-0.130 \\
(0.083)\end{array}$ & $\begin{array}{l}-0.027 \\
(0.079)\end{array}$ & $\begin{array}{l}-0.044 \\
(0.066)\end{array}$ & $\begin{array}{c}0.038 \\
(0.081)\end{array}$ \\
\hline$S A T V$ & & & $\begin{array}{c}0.200 \\
(0.012)\end{array}$ & $\begin{array}{c}0.113 \\
(0.012)\end{array}$ & $\begin{array}{c}0.110 \\
(0.013)\end{array}$ \\
\hline$S A T M$ & & & $\begin{array}{c}0.261 \\
(0.013)\end{array}$ & $\begin{array}{c}0.084 \\
(0.013)\end{array}$ & $\begin{array}{c}0.052 \\
(0.015)\end{array}$ \\
\hline$H S G P A$ & & & & $\begin{array}{c}0.597 \\
(0.016)\end{array}$ & $\begin{array}{c}0.722 \\
(0.020)\end{array}$ \\
\hline$A P$ & & & & $\begin{array}{c}0.013 \\
(0.001)\end{array}$ & $\begin{array}{c}0.011 \\
(0.001)\end{array}$ \\
\hline HS Fixed Effects & No & No & No & No & Yes \\
\hline$R^{2}$ & 0.076 & 0.124 & 0.246 & 0.394 & 0.513 \\
\hline$N$ & 7,022 & 7,022 & 6,940 & 6,918 & 6,916 \\
\hline
\end{tabular}

a Cumulative GPA is calculated through the spring quarter of the first year on the basis of credits earned since matriculation at UGA.

$b$ "Typical students" refers to those who matriculate at UGA in the fall term of the same year as they graduate from high school. 
Table 8

Estimated HOPE Effect on Cumulative GPA ${ }^{a}$

Typical Students ${ }^{b}, 1990$ and 95 Classes

(Robust Standard Errors in Parentheses)

\begin{tabular}{|c|c|c|c|}
\hline Variables & 1st-Year & 2nd-Year & 3rd-Yeal \\
\hline$G A \cdot H$ & $\begin{array}{c}0.130 \\
(0.057)\end{array}$ & $\begin{array}{c}0.072 \\
(0.055)\end{array}$ & $\begin{array}{c}0.081 \\
(0.056)\end{array}$ \\
\hline$H_{95}$ & $\begin{array}{l}-0.065 \\
(0.055)\end{array}$ & $\begin{array}{l}-0.006 \\
(0.053)\end{array}$ & $\begin{array}{l}-0.037 \\
(0.054)\end{array}$ \\
\hline$G A$ & $\begin{array}{l}-0.150 \\
(0.076)\end{array}$ & $\begin{array}{l}-0.161 \\
(0.079)\end{array}$ & $\begin{array}{l}-0.229 \\
(0.086)\end{array}$ \\
\hline$F E M A L E$ & $\begin{array}{c}0.045 \\
(0.016)\end{array}$ & $\begin{array}{c}0.082 \\
(0.015)\end{array}$ & $\begin{array}{c}0.088 \\
(0.015)\end{array}$ \\
\hline$A S I A N$ & $\begin{array}{l}-0.021 \\
(0.043)\end{array}$ & $\begin{array}{l}-0.057 \\
(0.043)\end{array}$ & $\begin{array}{l}-0.082 \\
(0.045)\end{array}$ \\
\hline$B L A C K$ & $\begin{array}{l}-0.074 \\
(0.035)\end{array}$ & $\begin{array}{l}-0.104 \\
(0.033)\end{array}$ & $\begin{array}{l}-0.102 \\
(0.031)\end{array}$ \\
\hline$H I S P N$ & $\begin{array}{l}-0.162 \\
(0.097)\end{array}$ & $\begin{array}{l}-0.047 \\
(0.077)\end{array}$ & $\begin{array}{l}-0.117 \\
(0.082)\end{array}$ \\
\hline OTHER & $\begin{array}{c}0.038 \\
(0.081)\end{array}$ & $\begin{array}{c}0.042 \\
(0.071)\end{array}$ & $\begin{array}{c}0.009 \\
(0.067)\end{array}$ \\
\hline$H S G P A$ & $\begin{array}{c}0.722 \\
(0.020)\end{array}$ & $\begin{array}{c}0.681 \\
(0.018)\end{array}$ & $\begin{array}{c}0.637 \\
(0.018)\end{array}$ \\
\hline$S A T V$ & $\begin{array}{c}0.110 \\
(0.013)\end{array}$ & $\begin{array}{c}0.084 \\
(0.012)\end{array}$ & $\begin{array}{c}0.066 \\
(0.012)\end{array}$ \\
\hline$S A T M$ & $\begin{array}{c}0.052 \\
(0.015)\end{array}$ & $\begin{array}{c}0.040 \\
(0.013)\end{array}$ & $\begin{array}{c}0.025 \\
(0.013)\end{array}$ \\
\hline$A P$ & $\begin{array}{c}0.011 \\
(0.001)\end{array}$ & $\begin{array}{c}0.009 \\
(0.001)\end{array}$ & $\begin{array}{c}0.009 \\
(0.001)\end{array}$ \\
\hline HS Fixed Effects & Yes & Yes & Yes \\
\hline$R^{2}$ & 0.513 & 0.546 & 0.532 \\
\hline$N$ & 6,916 & 6,224 & 5,706 \\
\hline
\end{tabular}

${ }^{a}$ Cumulative GPA is the average of earned grade points accumulated since a student matriculated at UGA.

$b$ "Typical students" refers to those who matriculate at UGA in the fall term of the same year as they graduate from high school. 
Table 9

Estimated HOPE Effect on Course Selection

by Core Curriculum Area $^{a}$

Typical First-Year Students ${ }^{b}$, 1989-97 Classes

(Robust Standard Errors in Parentheses)

\begin{tabular}{|c|c|c|c|c|c|c|c|c|c|}
\hline \multirow[b]{2}{*}{ Variables } & \multicolumn{3}{|c|}{ Enrolled Hours } & \multicolumn{3}{|c|}{ Withdrawn Hours } & \multicolumn{3}{|c|}{ Completed Hours } \\
\hline & I & II & III & I & II & III & I & II & III \\
\hline$G A \cdot H$ & $\begin{array}{l}-0.438 \\
(0.310)\end{array}$ & $\begin{array}{l}-0.222 \\
(0.286)\end{array}$ & $\begin{array}{c}0.437 \\
(0.308)\end{array}$ & $\begin{array}{c}0.136 \\
(0.087)\end{array}$ & $\begin{array}{c}0.409 \\
(0.101)\end{array}$ & $\begin{array}{c}0.103 \\
(0.080)\end{array}$ & $\begin{array}{l}-0.573 \\
(0.306)\end{array}$ & $\begin{array}{l}-0.631 \\
(0.285)\end{array}$ & $\begin{array}{c}0.334 \\
(0.310)\end{array}$ \\
\hline$G A$ & $\begin{array}{l}-0.350 \\
(0.454)\end{array}$ & $\begin{array}{c}0.012 \\
(0.444)\end{array}$ & $\begin{array}{c}-0.372 \\
(0.481)\end{array}$ & $\begin{array}{l}-0.129 \\
(0.162)\end{array}$ & $\begin{array}{l}-0.145 \\
(0.161)\end{array}$ & $\begin{array}{c}0.134 \\
(0.143)\end{array}$ & $\begin{array}{c}-0.221 \\
(0.460)\end{array}$ & $\begin{array}{c}0.156 \\
(0.446)\end{array}$ & $\begin{array}{l}-0.506 \\
(0.491)\end{array}$ \\
\hline$F E M A L E$ & $\begin{array}{c}0.945 \\
(0.090)\end{array}$ & $\begin{array}{l}-1.373 \\
(0.092)\end{array}$ & $\begin{array}{l}-0.408 \\
(0.095)\end{array}$ & $\begin{array}{l}-0.075 \\
(0.025)\end{array}$ & $\begin{array}{l}-0.175 \\
(0.034)\end{array}$ & $\begin{array}{c}0.036 \\
(0.024)\end{array}$ & $\begin{array}{c}1.020 \\
(0.090)\end{array}$ & $\begin{array}{l}-1.198 \\
(0.091)\end{array}$ & $\begin{array}{l}-0.443 \\
(0.095)\end{array}$ \\
\hline$A S I A N$ & $\begin{array}{l}-1.121 \\
(0.243)\end{array}$ & $\begin{array}{c}0.384 \\
(0.274)\end{array}$ & $\begin{array}{c}-1.719 \\
(0.262)\end{array}$ & $\begin{array}{c}0.226 \\
(0.090)\end{array}$ & $\begin{array}{l}-0.038 \\
(0.093)\end{array}$ & $\begin{array}{l}-0.021 \\
(0.067)\end{array}$ & $\begin{array}{l}-1.347 \\
(0.247)\end{array}$ & $\begin{array}{c}0.422 \\
(0.269)\end{array}$ & $\begin{array}{l}-1.698 \\
(0.259)\end{array}$ \\
\hline$B L A C K$ & $\begin{array}{l}-0.951 \\
(0.170)\end{array}$ & $\begin{array}{c}0.057 \\
(0.177)\end{array}$ & $\begin{array}{l}-2.147 \\
(0.182)\end{array}$ & $\begin{array}{l}-0.101 \\
(0.048)\end{array}$ & $\begin{array}{l}-0.268 \\
(0.066)\end{array}$ & $\begin{array}{l}-0.124 \\
(0.046)\end{array}$ & $\begin{array}{l}-0.850 \\
(0.171)\end{array}$ & $\begin{array}{c}0.326 \\
(0.173)\end{array}$ & $\begin{array}{l}-2.023 \\
(0.181)\end{array}$ \\
\hline$H I S P N$ & $\begin{array}{l}-0.340 \\
(0.539)\end{array}$ & $\begin{array}{l}-0.067 \\
(0.488)\end{array}$ & $\begin{array}{l}-1.926 \\
(0.497)\end{array}$ & $\begin{array}{l}-0.044 \\
(0.122)\end{array}$ & $\begin{array}{l}-0.242 \\
(0.160)\end{array}$ & $\begin{array}{c}0.117 \\
(0.140)\end{array}$ & $\begin{array}{l}-0.296 \\
(0.541)\end{array}$ & $\begin{array}{c}0.174 \\
(0.476)\end{array}$ & $\begin{array}{l}-2.043 \\
(0.512)\end{array}$ \\
\hline OTHER & $\begin{array}{l}-0.360 \\
(0.469)\end{array}$ & $\begin{array}{l}-0.480 \\
(0.434)\end{array}$ & $\begin{array}{l}-1.343 \\
(0.415)\end{array}$ & $\begin{array}{c}0.178 \\
(0.147)\end{array}$ & $\begin{array}{c}0.016 \\
(0.164)\end{array}$ & $\begin{array}{l}-0.099 \\
(0.110)\end{array}$ & $\begin{array}{l}-0.539 \\
(0.481)\end{array}$ & $\begin{array}{l}-0.496 \\
(0.433)\end{array}$ & $\begin{array}{l}-1.244 \\
(0.406)\end{array}$ \\
\hline$H S G P A$ & $\begin{array}{l}-0.006 \\
(0.111)\end{array}$ & $\begin{array}{c}2.447 \\
(0.111)\end{array}$ & $\begin{array}{c}0.570 \\
(0.120)\end{array}$ & $\begin{array}{c}-0.363 \\
(0.034)\end{array}$ & $\begin{array}{l}-0.418 \\
(0.040)\end{array}$ & $\begin{array}{l}-0.276 \\
(0.032)\end{array}$ & $\begin{array}{c}0.357 \\
(0.111)\end{array}$ & $\begin{array}{c}2.865 \\
(0.110)\end{array}$ & $\begin{array}{c}0.846 \\
(0.119)\end{array}$ \\
\hline$S A T V$ & $\begin{array}{c}0.935 \\
(0.072)\end{array}$ & $\begin{array}{l}-1.203 \\
(0.071)\end{array}$ & $\begin{array}{c}0.224 \\
(0.075)\end{array}$ & $\begin{array}{c}0.042 \\
(0.020)\end{array}$ & $\begin{array}{c}0.027 \\
(0.025)\end{array}$ & $\begin{array}{l}-0.110 \\
(0.019)\end{array}$ & $\begin{array}{c}0.892 \\
(0.071)\end{array}$ & $\begin{array}{l}-1.229 \\
(0.070)\end{array}$ & $\begin{array}{c}0.334 \\
(0.074)\end{array}$ \\
\hline$S A T M$ & $\begin{array}{l}-0.691 \\
(0.081)\end{array}$ & $\begin{array}{c}1.036 \\
(0.082)\end{array}$ & $\begin{array}{l}-0.635 \\
(0.085)\end{array}$ & $\begin{array}{c}0.037 \\
(0.023)\end{array}$ & $\begin{array}{l}-0.286 \\
(0.029)\end{array}$ & $\begin{array}{c}0.035 \\
(0.023)\end{array}$ & $\begin{array}{l}-0.728 \\
(0.081)\end{array}$ & $\begin{array}{c}1.323 \\
(0.080)\end{array}$ & $\begin{array}{l}-0.670 \\
(0.084)\end{array}$ \\
\hline Class Year Effects & Yes & Yes & Yes & Yes & Yes & Yes & Yes & Yes & Yes \\
\hline HS Fixed Effects & Yes & Yes & Yes & Yes & Yes & Yes & Yes & Yes & Yes \\
\hline$R^{2}$ & 0.162 & 0.147 & 0.175 & 0.105 & 0.107 & 0.089 & 0.159 & 0.161 & 0.182 \\
\hline$N$ & 22,802 & 22,802 & 22,802 & 22,802 & 22,802 & 22,802 & 22,802 & 22,802 & 22,802 \\
\hline
\end{tabular}

a Number of credit hours (i) enrolled, (ii) withdrawn, or (iii) taken by a typical first-year student in each general core curriculum area: Area I-Humanities and Fine Arts, Area II-Mathematics and Natural Sciences, and Area III-Social Sciences. Note that (iii) = (i) - (ii).

$b$ "Typical students" refers to those who matriculate at UGA in the fall term of the same year as they graduate from high school. 
Table 10

Estimated HOPE Effect Course Selection by General Core Curriculum Area ${ }^{a}$

Typical First- and Second-Year Students ${ }^{b}$, 1989-97 Classes

(Robust Standard Errors in Parentheses)

\begin{tabular}{|c|c|c|c|c|c|c|}
\hline \multirow[b]{2}{*}{ Variables } & \multicolumn{3}{|c|}{ 1st-Year } & \multicolumn{3}{|c|}{ 2nd-Year } \\
\hline & $\mathrm{I}$ & II & III & I & II & III \\
\hline \multicolumn{7}{|c|}{ A. Credit Hours Enrolled } \\
\hline$G A \cdot H$ & $\begin{array}{l}-0.438 \\
(0.310)\end{array}$ & $\begin{array}{l}-0.222 \\
(0.286)\end{array}$ & $\begin{array}{c}0.437 \\
(0.308)\end{array}$ & $\begin{array}{c}0.861 \\
(0.426)\end{array}$ & $\begin{array}{l}-0.312 \\
(0.371)\end{array}$ & $\begin{array}{l}-0.012 \\
(0.359)\end{array}$ \\
\hline$R^{2}$ & 0.162 & 0.147 & 0.175 & 0.146 & 0.126 & 0.139 \\
\hline \multicolumn{7}{|c|}{ B. Credit Hours Withdrawn } \\
\hline$G A \cdot H$ & $\begin{array}{c}0.136 \\
(0.087)\end{array}$ & $\begin{array}{c}0.409 \\
(0.101)\end{array}$ & $\begin{array}{c}0.103 \\
(0.080)\end{array}$ & $\begin{array}{c}0.261 \\
(0.105)\end{array}$ & $\begin{array}{c}0.250 \\
(0.133)\end{array}$ & $\begin{array}{c}0.056 \\
(0.103)\end{array}$ \\
\hline$R^{2}$ & 0.105 & 0.107 & 0.089 & 0.121 & 0.104 & 0.095 \\
\hline \multicolumn{7}{|c|}{ C. Credit Hours Taken ${ }^{c}$} \\
\hline$G A \cdot H$ & $\begin{array}{c}-0.573 \\
(0.306)\end{array}$ & $\begin{array}{c}-0.631 \\
(0.285)\end{array}$ & $\begin{array}{c}0.334 \\
(0.310)\end{array}$ & $\begin{array}{c}0.600 \\
(0.416)\end{array}$ & $\begin{array}{c}-0.563 \\
(0.355)\end{array}$ & $\begin{array}{l}-0.068 \\
(0.351)\end{array}$ \\
\hline$R^{2}$ & 0.159 & 0.161 & 0.182 & 0.143 & 0.127 & 0.136 \\
\hline Class Year Effects & Yes & Yes & Yes & Yes & Yes & Yes \\
\hline Residency & Yes & Yes & Yes & Yes & Yes & Yes \\
\hline Gender and Race & Yes & Yes & Yes & Yes & Yes & Yes \\
\hline HS Achievements & Yes & Yes & Yes & Yes & Yes & Yes \\
\hline HS Fixed Effects & Yes & Yes & Yes & Yes & Yes & Yes \\
\hline$N$ & 22,802 & 22,802 & 22,802 & 16,529 & 16,529 & 16,529 \\
\hline
\end{tabular}

${ }^{a}$ General core courses are decomposed into three areas: Area I-Humanities and Fine Arts, Area II-Mathematics and Natural Sciences, and Area III-Social Sciences.

$b$ "Typical students" refers to those who matriculate at UGA in the fall term of the same year as they graduate from high school.

${ }^{c}$ Credit hours taken $=$ Credit hours enrolled - Credit hours withdrawn. 
Table 11

Multinomial Logit Estimates for Major Choice Typical First-Year Students, 1989-97 Classes

(Robust Standard Errors in Parentheses)

\begin{tabular}{|c|c|c|c|c|c|}
\hline \multirow[b]{2}{*}{ Variables } & \multicolumn{5}{|c|}{$\begin{array}{c}\text { Unspecified Arts and Sciences } \\
\text { vs. }\end{array}$} \\
\hline & $(1)^{a}$ & $(2)^{a}$ & $(3)^{a}$ & $(4)^{a}$ & $(5)^{a}$ \\
\hline$G A \cdot H$ & $\begin{array}{l}-0.031 \\
(0.100)\end{array}$ & $\begin{array}{l}-0.032 \\
(0.112)\end{array}$ & $\begin{array}{l}-0.137 \\
(0.101)\end{array}$ & $\begin{array}{l}0.168 \\
(0.153)\end{array}$ & $\begin{array}{l}-0.061 \\
(0.141)\end{array}$ \\
\hline$H$ & $\begin{array}{l}-0.020 \\
(0.091)\end{array}$ & $\begin{array}{c}0.148 \\
(0.106)\end{array}$ & $\begin{array}{l}-0.163 \\
(0.095)\end{array}$ & $\begin{array}{c}0.221 \\
(0.144)\end{array}$ & $\begin{array}{c}0.518 \\
(0.132)\end{array}$ \\
\hline$G A$ & $\begin{array}{l}-0.238 \\
(0.074)\end{array}$ & $\begin{array}{c}0.039 \\
(0.087)\end{array}$ & $\begin{array}{l}-0.089 \\
(0.074)\end{array}$ & $\begin{array}{c}0.086 \\
(0.115)\end{array}$ & $\begin{array}{c}0.066 \\
(0.111)\end{array}$ \\
\hline$F E M A L E$ & $\begin{array}{c}0.193 \\
(0.041)\end{array}$ & $\begin{array}{l}-0.396 \\
(0.039)\end{array}$ & $\begin{array}{l}-0.580 \\
(0.036)\end{array}$ & $\begin{array}{l}1.168 \\
(0.068)\end{array}$ & $\begin{array}{l}-0.188 \\
(0.052)\end{array}$ \\
\hline$A S I A N$ & $\begin{array}{c}-0.356 \\
(0.125)\end{array}$ & $\begin{array}{c}0.477 \\
(0.089)\end{array}$ & $\begin{array}{l}-0.412 \\
(0.107)\end{array}$ & $\begin{array}{l}-1.165 \\
(0.229)\end{array}$ & $\begin{array}{l}-1.214 \\
(0.221)\end{array}$ \\
\hline$B L A C K$ & $\begin{array}{c}-0.185 \\
(0.078)\end{array}$ & $\begin{array}{c}0.859 \\
(0.061)\end{array}$ & $\begin{array}{c}0.208 \\
(0.068)\end{array}$ & $\begin{array}{c}-0.599 \\
(0.097)\end{array}$ & $\begin{array}{l}-0.778 \\
(0.108)\end{array}$ \\
\hline$H I S P N$ & $\begin{array}{c}0.087 \\
(0.179)\end{array}$ & $\begin{array}{c}0.581 \\
(0.167)\end{array}$ & $\begin{array}{c}0.027 \\
(0.192)\end{array}$ & $\begin{array}{l}-0.907 \\
(0.395)\end{array}$ & $\begin{array}{l}-0.140 \\
(0.264)\end{array}$ \\
\hline OTHER & $\begin{array}{c}0.111 \\
(0.178)\end{array}$ & $\begin{array}{l}0.343 \\
(0.177)\end{array}$ & $\begin{array}{l}-0.714 \\
(0.245)\end{array}$ & $\begin{array}{l}-0.470 \\
(0.343)\end{array}$ & $\begin{array}{l}-0.811 \\
(0.351)\end{array}$ \\
\hline$H S G P A$ & $\begin{array}{l}0.025 \\
(0.046)\end{array}$ & $\begin{array}{c}0.989 \\
(0.048)\end{array}$ & $\begin{array}{l}1.250 \\
(0.043)\end{array}$ & $\begin{array}{l}0.354 \\
(0.067)\end{array}$ & $\begin{array}{c}0.116 \\
(0.067)\end{array}$ \\
\hline$S A T V$ & $\begin{array}{c}0.550 \\
(0.029)\end{array}$ & $\begin{array}{l}-0.090 \\
(0.029)\end{array}$ & $\begin{array}{l}-0.041 \\
(0.027)\end{array}$ & $\begin{array}{l}-0.115 \\
(0.041)\end{array}$ & $\begin{array}{l}-0.176 \\
(0.040)\end{array}$ \\
\hline$S A T M$ & $\begin{array}{l}-0.042 \\
(0.037)\end{array}$ & $\begin{array}{c}0.579 \\
(0.034)\end{array}$ & $\begin{array}{c}0.724 \\
(0.033)\end{array}$ & $\begin{array}{c}-0.092 \\
(0.052)\end{array}$ & $\begin{array}{c}0.091 \\
(0.047)\end{array}$ \\
\hline$A P$ & $\begin{array}{c}0.010 \\
(0.003)\end{array}$ & $\begin{array}{l}-0.002 \\
(0.003)\end{array}$ & $\begin{array}{l}-0.052 \\
(0.003)\end{array}$ & $\begin{array}{l}-0.034 \\
(0.006)\end{array}$ & $\begin{array}{l}-0.017 \\
(0.005)\end{array}$ \\
\hline HS Weights & Yes & Yes & Yes & Yes & Yes \\
\hline Scaled $R^{2}$ & & & 0.173 & & \\
\hline Likelihood Ratio & & & $5,650.14$ & & \\
\hline$N$ & & & 30,679 & & \\
\hline
\end{tabular}

${ }^{a}$ (1) Fine Arts, Humanities and Social Sciences; (2) Math and Sciences; (3) Business; (4) Education; (5) Other Majors. 
Table 12

Estimated HOPE Effect on Major Choice ${ }^{a}$

by Individual Characteristics

Typical First-Year Students, 1989-97 Classes

(Robust Standard Errors in Parentheses)

\begin{tabular}{lcccccc}
\hline & $(1)^{b}$ & $(2)^{b}$ & $(3)^{b}$ & $(4)^{b}$ & $(5)^{b}$ & $(6)^{b}$ \\
\hline \hline On Average & & & & & \\
Average Student $^{c}$ & 0.000 & -0.001 & -0.017 & 0.012 & 0.000 & 0.007 \\
Gender & $(0.012)$ & $(0.012)$ & $(0.015)$ & $(0.006)$ & $(0.008)$ & $(0.017)$ \\
Female & & & & & \\
& -0.002 & -0.002 & -0.015 & 0.019 & -0.001 & 0.002 \\
Male & $(0.013)$ & $(0.011)$ & $(0.012)$ & $(0.010)$ & $(0.008)$ & $(0.017)$ \\
& 0.001 & 0.001 & -0.020 & 0.006 & 0.001 & 0.011 \\
Race & $(0.011)$ & $(0.014)$ & $(0.018)$ & $(0.003)$ & $(0.008)$ & $(0.017)$ \\
White & & & & & \\
& 0.000 & -0.001 & -0.018 & 0.013 & 0.000 & 0.006 \\
Asian & $(0.012)$ & $(0.011)$ & $(0.015)$ & $(0.007)$ & $(0.009)$ & $(0.017)$ \\
& 0.000 & -0.001 & -0.012 & 0.005 & 0.000 & 0.009 \\
Black & $(0.010)$ & $(0.019)$ & $(0.012)$ & $(0.003)$ & $(0.003)$ & $(0.019)$ \\
& 0.000 & 0.001 & -0.017 & 0.007 & 0.000 & 0.009 \\
Hispanic & $(0.010)$ & $(0.020)$ & $(0.016)$ & $(0.003)$ & $(0.004)$ & $(0.017)$ \\
Others & 0.001 & 0.000 & -0.015 & 0.005 & 0.000 & 0.009 \\
& $(0.013)$ & $(0.017)$ & $(0.014)$ & $(0.003)$ & $(0.007)$ & $(0.017)$ \\
& -0.001 & -0.002 & -0.010 & 0.009 & 0.000 & 0.005 \\
\hline \hline
\end{tabular}

${ }^{a}$ Probability of choosing major $j(j=1, \ldots, 6)$ in the first quarter at UGA.

${ }^{b}$ (1) Fine Arts, Humanities and Social Sciences; (2) Math and Sciences; (3) Business; (4) Education; (5) Other Majors; (6) Unspecified Arts and Sciences.

${ }^{c}$ HOPE effects (i.e., interaction effects between HOPE-period and GA-residency dummies) computed based on logit estimates in Table 11 and at the means of the independent variables in the model (0.575 for FEMALE, 0.028 for ASI AN, 0.088 for BLACK, 0.009 for HISPN, 0.008 for OTHER, 3.258 for HSGPA, 5.961 for $S A T V, 5.754$ for $S A T M, 3.919$ for $A P$ and 0.084 for high-school weights. Note that $S A T V$ and $S A T M$ are in 100 points). 